\title{
AKULTURASI ESTETIKA SEBAGAI MODAL UNTUK MENGHADAPI PERTUKARAN KESENIAN DALAM MASYARAKAT EKONOMI ASEAN (Sebuah Kajian Holistik Terhadap Perkembangan Kesenian Modern di Indonesia)
}

\author{
Vedy Santoso \\ vedysantosa@gmail.com
}

\begin{abstract}
Abstrak
Masyarakat ekonomi ASEAN (MEA) adalah program kerjasama internasional yang menjadi usaha negara-negara anggota ASEAN untuk memperluas pasar. Dengan terjalinya kerjasama di segala bidang termasuk seni dan budaya, maka kesenian akan memasuki era konseptual "baru”. Sebuah era yang secara ekonomi penting dan berharga secara personal. Nilai keindahan seni (estetika) akan dihadapkan oleh tuntutan nuansa fantastis namun juga harus menarik secara emosional. Selain itu, masyarakat penyangga pada era konseptual ini memiliki corak maya yang hidup dalam dunia yang penuh dengan simulasi. Sehingga untuk menghadapi MEA diperlukan faktor daya modal sebagai benteng pertukaran seni. Metode holistik dalam penelitian ini digunakan untuk : (1) Menjelaskan konsep akulturasi estetika sebagai sebuah toleransi masyarakat dalam berbudaya dengan pendekatan sosio-historis, (2) Menganalisis hubungan perkembangan teknologi informasi dengan kesenian modern yang telah melampaui batas-batasnya dan menjalar keseluruh sendi-sendi kehidupan masyarakat modern dari sudut pandang konvensi komunikasi massa. Data penelitian diperoleh dari pengamatan terhadap fenomena munculnya budaya populer di Indonesia, objek materi kesenian modern dan studi pustaka. Hasil pengkajian menunjukkan bahwa akulturasi estetika dapat menjadi daya modal alternatif dalam proses pertukaran seni dan interaksi sosial masyarakat ekonomi ASEAN. Namun dengan catatan kerjasama internasional yang dilakukaan merupakan sebuah aktivitas pertukaran dalam perspektif pasar yang berarti tempat bertemunya penjual dan pembeli dengan tujuan yang saling menguntungkan. Bukan sebuah perdagangan dengan tujuan untuk saling menguasai yang berpotensi pada penjajahan.
\end{abstract}

Kata Kunci : masyarakat, estetika dan akulturasi.

\begin{abstract}
ASEAN Economic Community (AEC) is a program of international cooperation into the business of ASEAN member countries to expand the market. With coop-eration in all fields including the arts and culture, it will enter the era of conceptual art "new". An era which are economically important and valuable personal. The value of the beauty of art (aesthetics) to be confronted by the demands of the fantastic shades, but also must be emotionally appealing. In addition, public support on this conceptual era has a style of living in a virtual world filled with simulations. So, as to face the AEC required power factor capital as a bastion of art exchange. Holistic method in this study is used for: (1) explain aesthetics acculturation concept as a culture of tolerance in the society with the socio-historical approach, (2) analyze the relationship development of information technology and artistry that has gone beyond limits and spread throughout the joints of modern society from the standpoint of mass communication convention. Data were obtained from observations of the phenomenon of the rise of popular culture in Indonesia, material objects of art and literature. The study showed that acculturation aesthetics can be an alternative capital in the process of artistic exchange and social interaction ASEAN economic community. But with a record of international cooperation is an activity in the exchange market perspective, which means meeting place for sellers and buyers with mutually beneficial goals. Not a trade aimed at mutual control of potential colonization.
\end{abstract}

Keywords : community, aestethic and acculturation. 


\section{Pendahuluan}

Masyarakat ekonomi ASEAN (MEA) adalah program kerjasama internasional yang menjadi usaha negara-negara anggota ASEAN untuk memperluas pasar. Dalam logika pasar, faktor modal merupakan unsur penting untuk melakukan aktivitas pertukaran.

Dengan terjalinnya kerja sama di segala bidang, tak terkecuali seni dan budaya diharapkan dapat memberikan kontribusi positif pada pertumbuhan ekonomi negaranegara ASEAN. Namun anehnya masih terjadi penyimpangan logis soal kesiapan Negara anggota ASEAN yang notabene memiliki modal seni dan budaya masing-masing, tidak terkecuali Indonesia. Masalahnya terletak pada sistem pasar bebas dalam program kerjasama internasional ini. Dimana tujuan diberlakukannya MEA yakni, demi membentuk pasar tunggal dan kesatuan berbasis produksi di kawasan Asia Tenggara, namun sejauh mana kebebasan itu akan diterapkan belum dapat dipastikan. Sehingga globalisasi menjadi ancaman terkikisnya identitas tradisi sebagai dampak negatifnya, jika pertukaran seni dan budaya tidak seimbang. Karena sekurang-kurangnya pertukaran ekspresi individu akan menjadi kompetisi baru yang mewarnai ekspresi kolektif masyarakat menembus batas lingkaran teritorial Negara. Hasilnya mitos kalah-menang dan untung-rugi sedang menghantui kesiapan setiap negara anggota ASEAN untuk mengahadapinya. Maka agar globalisasi tidak menjadi mitos kekalahan atau kerugian perlu adanya kesetaraan faktor daya modal pada masing-masing pelaku pertukaran.

Berdasarkan latarbelakang diatas kemudian pertanyaan berikutnya, modal apa yang dimiliki oleh bangsa Indonesia sebagai salah satu negara anggota ASEAN untuk menghadapi kompetisi global ini, jika ternyata faktor sumber daya manusia, faktor sumber daya alam, faktor budaya, faktor ilmu pengetahuan dan teknologi masih menjadi momok kesiapan sistemnya?

Hal ini nampak pada peringkat daya saing Indonesia periode 2012-2013 berada di posisi 50 dari 144 negara, masih berada di bawah Singapura yang di posisi kedua, Malaysia di posisi ke dua puluh lima, Brunei Darussalam di posisi dua puluh delapan, dan Thailand di posisi tiga puluh delapan. Akankah identitas kesenian Indonesia akan terkikis oleh globalisasi di masa depan? Maka untuk menjawab tantangan ini pertamatama penulis akan mengkaji hubungan pola sejarah seni, masyarakat dan estetika di Indonesia sebagai prediksi. Kemudian baru menganalisis modal apa yang dimiliki oleh bangsa Indonesia untuk menghadapi MEA.

Bermula dari catatan sejarah yang menunjukan bahwa akulturasi pernah berhasil di Nusantara sebagai sebuah toleransi masyarakat dalam berbudaya. Asumsi ini berawal dari kebimbangan estetika yang membahas permasalahan tentang pengaruh barat di bidang estetika yang cukup besar. Denys Lombart seorang antropolog dari Eropa pernah mengkaji batas-batas pembaratan yang terkandung dalam budaya Nusantara khususnya pulau Jawa pasca era Kolonialisme (Lombart, 1996:1). Perspektif yang digunakan adalah Eropasentris dalam melihat peleburan budaya di Nusantara, karena menurut Denys Lombart hanya di Nusantara, tempat kehadiran hampir semua kebudayaan besar dunia dari peradapan klasik, seperti peradaban Eropa, Islam, India atau China dapat melebur menjadi satu. Logika peleburan budaya inilah yang kemudian menjadi dasar gagasan penulis mengusung topik akulturasi estetika untuk dikaji sebagai alternatif. 
Namun pasca era kolonialisme konfrontasi budaya sangat kuat terjadi khususnya di Jawa, justru antara tradisi lama dan tradisi yang baru. Artinya terjadi pertentangan antara bobot warisan budaya dan kerasnya dampak budaya lain. Dilema dasar yang menyebabkanya adalah pada satu sisi para seniman harus bangkit dari kelelapan masa lalu dan menjadi baru, namun pada saat yang sama, mereka harus menciptakan suatu budaya nasional yang — untuk dapat lestari — jelas harus berakar di masa lalu itu juga (Lihat Lombart, 1996:174). Hasilnya proses akulturasi dan semangat peleburan budaya di Jawa mulai luntur, karena aktivitas kesenian mulai bergeser pada kegiatan pencarian tentang identitas budaya nasional yang ternyata didasari oleh kepentingan sosial politik.

Dalam kasus dunia seni lukis misalnya, pencarian identitas bangsa dan pasang surutnya pergerakan nasional nampak pada tahun 1930-an sampai dengan pertengahan tahun 1960-an. Perubahan gaya lukisan dan aliran-aliran pemikiran saat itu, tidak hanya dilatar belakangi oleh kreativitas seniman saja, namun juga terbentuk atas dukungan masyarakat penyangga dan lembaga-lembaga kesenian (Lihat Agus Burhan, 2013:41). Hasil penelitian sejarah seni lukis Indonesia yang dilakukan oleh Agus Burhan menyebutkan bahwa paradigma kontekstualisme dari masa Persagi sampai Lekra tumbuh dari pengaruh-pengaruh sosial politik, yang di dominasi dengan menguatnya nasionalisme Indonesia. Berbagai isu dalam nasionalisme mempunyai interes yang berbeda-beda, yaitu dari yang bercorak antikolonialisme, pencarian nilai-nilai ke-Indonesiaan, sampai dengan perjuangan realitas kontekstual yang didasarkan pada moral perjuangan rakyat (Periksa Agus Burhan, 2013:112).

Dari kasus perubahan gaya lukisan dan aliran-aliran pemikiran di atas dapat kita pahami bahwa terdapat hubungan erat antara seni sebagai ekspresi individu dengan budaya sebagai ekspresi kolektif masyarakatnya. Masyarakat penyangga menjadi salah satu faktor penentu laju perkembangan sebuah paradigma estetika. Hal ini juga nampak pada masa munculnya lukisan-lukisan mooi indie, masyarakat penyangga yang dimaksudkan pada masa itu adalah masyarakat elite kolonial Belanda yang mengapresiasi lukisan-lukisan sebagai kolektor. Berangakat dari keterangan sejarah perkembangan seni lukis diatas dapat mejadi prediksi kiranya siapakah masyarakat penyangga pada era Ekonomi ASEAN kelak? Apakah nasibnya akan sama dengan era lukisan mooi indie? Tentunya semangat jiwa zaman era MEA memiliki konteks yang berbeda.

Oleh sebab itu terlebih dahulu kita perlu melihat konteks fenomena perubahan bentuk kesenian lainnya. Seperti perkembangan medium presentasi pertunjukan menuju medium presentasi media rekam sebagai akibat dari perkembangan kemajuan teknologi.

\section{Tradisi Kesenian Digital}

Seni pertunjukan merupakan seni yang paling tua dalam peradaban manusia. Dalam paradigma komunikasi, seni pertunjukan terikat dengan ruang dan waktu sebenarnya, seperti dalam teater, musik panggung, dan sejenisnya. Namun pada penghujung abad $19 \mathrm{M}$, ketika teknologi pembuatan film ditemukan di Prancis, tepatnya pada tanggal 28 Desember 1895, dunia per- tunjukan dikejutkan dengan penemuan gambar yang bisa bergerak. Saat itu negeri Nusantara ini masih menjadi jajahan Belanda yang populer dengan nama Hindia Belanda. Pada mulanya tontonan panggung yang paling digemari 
masyarakat Hindia Belanda masa itu berupa tiruan opera yang disisipi oleh adegan hiburan. Sampai akhirnya pada penghujung 1900, masyarakat Hindia Belanda dapat menyaksikan pertunjukan gambar hidup dalam balutan teknologi media rekam film. Akhirnya pengaruh modernisasi membawa serta hijrahnya orang panggung ke film dan lambat laun tontonan panggung pun mulai terpuruk (Periksa Misbach, 2009:21).

Dari fenomena hijrahnya orang panggung ke film diatas penulis hendak memberikan gambaran tentang desensualisasi atau proses peniadaan ciri corak indrawi yang terjadi pada medium film sebagai panggung pertunjukan yang baru. Di mana teknologi dapat menyatukan seni ruang dan seni waktu. Seni ruang secara sederhana dapat dipahami sebagai kriterium penjenjangan seni yang menciptakan sesuatu yang tetap dalam ruang, sedangkan seni waktu adalah kriterium penjenjangan seni yang menciptakan sesuatu yang sementara atau sesuatu yang harus selalu diperbaharui dalam waktu. Sehingga dapat dikatakan bahwa teknologi media rekam film saat itu, telah menembus batas ruang dan waktu dalam menyajikan dimensi baru berupa simulasi sebagai tontonan masyarakat.

Rupanya perkembangan pesat teknologi diakhir abad 20 dan awal millennium ketiga ini telah melampaui batas-batasnya dan menjalar keseluruh sendi-sendi kehidupan manusia dan mengubah secara radikal cara pandang manusia terhadap dunia. Hal ini ditandai dengan cara hidup manusia abad kontemporer dalam dunia simulacra (gambar, citra atau penanda suatu peristiwa yang telah menggantikan pengalaman). Manusia abad kontemporer hidup dalam du- nia yang penuh dengan simulasi, tidak ada yang nyata di luar simulasi, tidak ada yang asli yang dapat ditiru. Nilai guna komoditas dan nilai imperatif sebuah produksi-pun telah digantikan oleh model, kode, tontonan dan hiperrealisme "simulasi". Teori ini dikemukakan oleh Baudril- lard seorang pemikir aliran postmodern yang perhatian utamanya pada hakikat dan pengaruh komunikasi dalam masyarakat pascamodern (Lihat Aziz, 2001:43).

Simulacra adalah sebuah tiruan dari tiruan (a copy of acopy of the real). Konsep Baudrillard mengenai simulacra beranjak dari penciptaan kenyataan melalui model konseptual yang berhubungan dengan "mitos" sehingga tidak dapat dilihat kebenarannya dalam kenyataan. Model ini menjadi faktor penentu pandangan masyarakat modern terhadap kenyataan. Segala yang dapat menarik minat manusia — seperti seni, ekonomi, politik dan lainnya - ditayangkan melalui berbagai media dengan model-model yang ideal, di sinilah batas antara simulasi dan kenyataan menjadi tercampur aduk sehingga menciptakan hyperreality dimana yang nyata dan yang tidak nyata menjadi tidak jelas.

Teori simulacra ini kemudian menjadi refleksi estetika para seniman kontemporer dalam menciptakan sebuah karya seni. Hal ini ditandai dengan sejarah gerakan postmodernisme pada tahun 1960-an yang memandang teknologi tidak lagi sebagai komoditi yang dijual, melainkan teknologi sebagai informasi dan simulasi digital. Dengan demikian pada masa postmodern titik refleksi estetika adalah simulacra, simulasi digital, virtual reality, hyper-reality dan hologram. Refleksi estetika era pascamodern berkutat dalam hal mereproduksi dan mendaur ulang, bukan memproduksi yang real, bahkan mereproduksi yang hyper-real. Sehingga tujuan dari refleksi simulacra adalah simulasi sempurna, di mana tidak ada lagi masalah orisinilitas sebagai titik banding dan tidak ada distingsi antara representasi dan yang real (Lihat Matinus Ali, 2004:191). 
Kemudian lebih jauh perkembangan teknologi digital dan teknologi informasi telah merevolusi cara membuat dan pengalaman seni saat ini. Tidak hanya merubah kebiasaan bentuk seni rupa seperti seni grafis, seni lukis, fotografi, bahkan seni pentunjukan telah menjelma dengan teknik digital dan media. Perkembangan lebih jauh seluruhnya memiliki bentuk baru seperti : seni jaringan, seni software, instalasi digital dan muncul realitas virtual yang diakui sebagai aktivitas artistik. Misalnya pada konsep cinema digital, terutama sekali papan area informasi (subtitle) sudah menghapus konsep merekam realitas dengan mengkombinasikan footage film dengan efek digital dan model tiga dimensi. Perkembangan kesenian kontemporer ini dicatat oleh kurator new media art (seni media baru) dari London, Cristiane Paul dalam bukunya Digital Art (Periksa Cristiane Paul, 2005:96).

Cristiane Paul menjelaskan, pada era new media art seperti sekarang ini, manusia akan terus melakukan eksplorasi kreatif untuk membuat sebuah karya seni menuju simulasi sempurna. Tanda-tanda ini nampak dalam tema-tema karya seni yang muncul setelah teknologi digital disempurnakan, misalnya: kehidupan tiruan (artificial life), kecerdasan tiruan dan perantara cerdas (artificial intelligence and intelligent agent), kehadiran jarak jauh dan mesin jarak jauh (telepresence, telematics, and telerobotics), sampai dengan game dan media sosial (gaming and social networking) (Lihat Cristiane Paul, 2005:139-238).

Sementara di Indonesia Krisna Murti salah seorang saksi sejarah kesenian modern di Indonesia khususnya perkembangan seni video dan multimedia mengungkapkan bahwa fungsionalisme dan hiburan telah menjadi arus besar masyarakat Indonesia dalam relasinya dengan media baru yang telah melampaui budaya visual. Faktanya selama ini, masyarakat Indonesia adalah pengguna bukan inovator. Media baru di Indonesia belum dianggap serius meskipun kenyataanya masyarakat Indonesia sudah diasuh oleh budaya itu lebih dari empat puluh tahun lalu. Padahal media baru dalam keseharian kita sudah banyak terbukti membantu pekerjaan juga kesenangan kita, namun masih sangat miskin kreativitas dalam memanfaatkanya sebagai alat pernyataan dan ekspresi budaya yang lebih luas. Lemahnya kesadaran masyarakat seni di Indonesia atas relasinya dengan lingkungan baru itu mempersulit kita juga mengkritisi diri dan kehidupan yang berubah cepat. Misalnya pada Biennale Jakarta 2006, ketika salah satu peserta memamerkan seni media baru telah melewatkan kesempatan dengan sibuk memperkarakan renda-renda visual seni rupa daripada mengaitkan media baru untuk memahami perubahan masyarakat masa kini yang sarat dipengaruhi oleh perluasan budaya visual. Ditambah lagi pada sesi seminarnya para peserta justru berkutat pada perbedaan pendapat tentang terminologi baru yang berimplikasi membongkar trauma lama pembaruan seni rupa seperti yang terjadi pada tahun 1974. Padahal yang lebih esensial adalah memahami budaya media baru yang di dalamnya terdiri dari: bahasa, perilaku, realitas, norma dan hukum baru. Sebuah tantangan untuk sebuah rujukan baru bersama, kini dan esok. (Lihat Krisna Murti, 2006:33-36).

Fenomena tradisi kesenian digital diatas dapat menjadi pertimbangan untuk memprediksi seperti apa karakter masyarakat penyangga pada era MEA kelak. Karena tidak dapat kita pungkiri bahwa masyarakat penyangga di era MEA sudah memiliki kedekatan dengan teknologi dan informasi, sehingga mereka juga sudah mulai hidup 
dalam dunia simulasi yang bersifat maya. Dalam perspektif sosiologi komunikasi, masyarakat maya merupakan sebuah kehidupan masyarakat manusia yang tidak dapat secara langsung diindera melalui penginderaan manusia, namun dapat dirasakan dan disaksikan sebagai sebuah realitas. Salah satu ciri masyarakat ini adalah menciptakan kebudayan maya, kebudayaan yang dikembangkan adalah budaya-budaya pencitraan dan makna yang setiap saat dipertukarkan dalam interaksi simbolis (Burhan Bungin, 2008:89).

Secara materi masyarakat maya mampu mengembangkan ruang gerak kehidupan baru bagi manusia sehingga tanpa disadari, komunitas manusia telah hidup dalam dua dunia kehidupan masyarakat, yaitu masyarakat nyata dan masyarakat maya (cybercommnunity). Masyarakat ekonomi ASEAN sebagai bentuk integrasi ekonomi ASEAN dalam artian adanya sistem perdagaangan bebas antara negara-negara ASEAN. Di mana Indonesia dan sembilan negara anggota ASEAN lainnya di antaranya: Malaysia, Filipina, Singapura, Thailand, Brunei Darussalam, Vietnam, Laos, Myanmar, dan Kamboja telah menyepakati perjanjian Masyarakat Ekonomi ASEAN (MEA) atau ASEAN Economic Community (AEC). Maka konvergensi kepentingan negara-negara anggota ASEAN untuk memperdalam dan memperluas integrasi ekonomi juga akan berpengaruh pada kehidupan seni secara global dengan bantuan teknologi informasi. Dengan demikian masyarakat peyangga dalam konteks Masyarakat Ekonomi ASEAN adalah mereka yang berada dalam komunias terbayang dan memiliki sistem pertukaran kesenian yang bebas. Mengenai sejauh apa bentuk kebebasan pertukaran kesenian itu dapat masuk dan keluar begitu saja dalam komunitas terbayang ini, Maka untuk menjawabnya penulis akan memaparkan gambaran tentang budaya masyarakat maya.

\section{Budaya Masyarakat Maya}

Berdasarkan fenomena budaya masyarakat maya yang bersifat global maka dapat diprediksi bahwa pertukaran kesenian yang akan timbul adalah jenis kesenian dari budaya populer. Sehingga untuk memahaminya penulis bertolak dari teori estetika Theodor W. Adorno yang mempertanyakan kondisi-kondisi yang mungkinkan sebuah karya seni tertentu lahir dan tumbuh pada periode sejarah tertentu. Dalam melihat hubungan antara seni, masyarakat dan estetika (art, society and aesthetic) Adorno menjadikan teori kritis sebagai dasar pemikiran, lalu merekonstruksi logika epistemologi seni melalui perspektif yang kontemporer. Maksudnya teori kritis diorientasikan pada ide tentang masyarakat sebagai subjek, dengan individu sebagai pusat dengan cara memahami permasalahan sesuai dengan kebutuhan jamannya, sehingga kita dapat mengambil posisi dalam membuat perspektif ganda menuju arah rekonsiliasi antara pandangan kapitalis dan sosialis sebagai pergeseran paradigma parsial ke paradigma global (Ardorno, 2002:1-15).

Penemuan dan perkembangan teknologi Informasi dalam skala massal, telah mengubah bentuk masyarakat manusia dari masyarakat dunia lokal menjadi masyarakat dunia global — sebuah dunia yang sangat transparan terhadap perkembangan informasi, transportasi, serta teknologi yang begitu cepat dan begitu besar yang mempengaruhi peradaban umat manusia. Masyarakat global merupakan suatu kehidupan yang memungkinkan komunitas manusia menghasilkan budaya-budaya bersama, menghasilkan 
produk-produk industri bersama, menciptakan pasar bersama, sampai dengan menggunakan mata uang bersama.

Berdasarkan teori estetika Ardorno dan fenomena masyarakat penyangga yang bersifat maya, maka untuk menghadapi dampak-dampak era MEA perlu diambil sebuah perspektif ganda menuju arah rekonsiliasi antara pandangan kapitalis dan sosialis sebagai pergeseran paradigma parsial ke paradigma global. Hal ini perlu dilakukan sebagai strategi penerapan sistem kapital yang bertujuan demi kesejahteraan sosial pada program kerja sama internasional ini. Sehingga rekonsiliasi pertukaran seni pada masyarakat ekonomi ASEAN perlu diantisipasi dengan konsep akulturasi sebagai usaha memperkuat modal pertukaran.

Dalam melihat hubungan budaya dan masyarakat Kuntowijoyo dari perspektif antropologi menjelaskan bahwa suatu sistem budaya memang tidak akan pernah berhenti. Ia mengalami perubahan dan perkembangan, baik karena dorongan dalam maupun dorongan luar. Interaksi antara komponen-komponen budaya dapat melahirkan bentukbentuk simbol baru. Demikian juga interaksi budaya dengan pengaruh-pengaruh luar sering dapat mengubah sistem budaya, baik komponennya atau bahkan keseluruhanya. Sehingga budaya dapat juga mengalami perubahan dengan masuknya atau hilangnya dasar-dasar ekologinya. (Kuntowijoyo, 2006 : xii). Secara universal terdapat kesamaankesaman unsur kebudayaan yang membangun suatu laju peradaban manusia. Dengan menganalisis berbagai kerangka tentang unsur-unsur kebudayaan universal yang disusun oleh para ahli antropologi, kemudian Koentjaraningrat dalam bukunya Pengantar Ilmu Antropologi (Koentjaraningrat, 1976: 165) telah membagi tujuh unsur kebudayaan yang dapat ditemukan pada semua bangsa di dunia. Ketujuh unsur kebudayaan universal itu adalah sebagai berikut :

1. Bahasa

2. Sistem pengetahuan

3. Organisasi sosial

4. Sisitem peralatan hidup dan teknologi

5. Sistem mata pencaharian hidup

6. Sistem religi

7. Kesenian

Masing-masing unsur kebudayaan universal diatas kemudian menjelma dalam tiga wujud kebudayaan, yaitu wujudnya yang berupa sistem budaya, sistem sosial dan wujud yang berupa unsur-unsur kebudayaan fisik.

Dari pemaparan landasan teori di atas maka menurut penulis fakta sejarah tentang keberhasilan akulturasi budaya di Nusantara perlu ditilik kembali sebagai sebuah konsep toleransi masyarakat ekonomi ASEAN dalam berkesenian. Akulturasi merupakan suatu proses sosial yang timbul bila suatu kelompok manusia dengan suatu kebudayaan tertentu dihadapkan dengan unsur-unsur dari suatu kebudayaan asing dengan sedemikian rupa, sehingga unsur-unsur kebudayaan asing itu lambat laun diterima dan diolah ke dalam kebudayaan sendiri tanpa menyebabkan hilangnya kepribadian kebudayaan itu sendiri (Koentjaraningrat, 1976:155). Sedangkan seni secara sederhana diartikan sebagai keterampilan manusia membuat sesuatu yang mengacu pada apa yang indah. Kajian tentang seni mengarah pada masalah estetika atau filsafat seni. Namun persoalan tentang 
bagaimana filsafat seni itu didefinisikan masih menjadi perdebatan yang tak berujung sampai sekarang. Pokok permasalahanya terletak pada nilai keindahan itu sendiri, dimana ia bersandar pada pengalaman estetik yang bersifat sujektif. Hasilnya prinsip-prinsip estetis terus berubah seiring dengan perkembangan zaman.

Dengan demikian yang penulis maksud dengan akulturasi estetika adalah sebuah pertukaran pengalaman estetik yang bersifat dialektika. Bukan sebuah perdagangan budaya yang akhirnya memunculkan pergulatan antara kategori budaya tinggi dengan budaya massa yang menyebabkan hilangnya nilai seni, karena tidak tepatnya segmentasi pasar. Melainkan sebuah kebebasan berekspresi yang telah dianugrahkan secara individu harus dapat bertanggung jawab terhadap perkembangan budaya sebagai ekspresi kolektif masyarakat. Sehingga di masa depan diharapkan aktifitas pertukaran estetika sebagai pengalaman berkesenian dapat menjadi sebuah proses eksplorasi dalam mengkomunikasikan gagasan yang kemudian dicurahkan dalam karya seni.

\section{Dilema Pertukaran Seni}

Bagaimana akulturasi estetika ini diaplikasikan dalam komunitas terbayang. Hal ini tentu akan menghadirkan dilema baru, pertukaran kesenian yang bersifat global memiliki ambivalensi. Dimana pada saat yang sama pasar bebas dalam masyarakat ekonomi ASEAN dapat di maknai sebagai kompetisi seni, namun juga dapat bermakna peperangan seni. Kedua pemaknaan ini akan saling bertentangan dari perspektif seniman dan pekerja seni. Dimana bagi seorang seniman kapital (sumber daya) ekonomi bukan menjadi tujuan yang harus dicapai pada era masyarakat ekonomi ASEAN. Sedangkan bagi perkerja seni era masyarakat ekonomi ASEAN menjadi tujuan kapital ekonomi. Padahal kapital ekonomi menurut Pierre Bourdieu merupakan sumber daya yang bisa menjadi sarana produksi dan sarana finansial. Kapital ini paling mudah di konversikan ke kapitalkapital lain (Haryatmoko, 2010:6).

Kapital ekonomi barulah tahap awal yang harus dilalui seniman untuk mencapai kapital simbolik dalam lingkup arena seni. Di mana kapital simbolik adalah semua bentuk pengakuan oleh kelompok baik secara institusional atau tidak. Lebih lanjut Bourdieu menjelaskan bahwa konsep kapital meskipun merupakan khasanah ilmu ekonomi, namun cirinya mampu menjelaskan hubungan-hubungan kekuasaan diantaranya: kapital terakumulasi melalui investasi, kapital bisa diwariskan, dan pada kapital terdapat modal yang dapat memberi keuntungan sesuai dengan kesempatan yang dimiliki oleh pemiliknya untuk mengoperasikan penempatanya. Artinya kapital merupakan energi sosial yang hanya ada dan membutuhkan hasil-hasil dalam arena perjuangan dimana ia memproduksi dan mereproduksi. Setiap kepemilikan yang terkait dengan kelas menerima nilainya dan efektivitasnya dari hukum-hukum khas setiap arena dalam prakteknya, dengan kata lain dalam suatu arena khusus semua disposisi dan kepemilikan obyektif (kekayaan ekonomi atau budaya) (Bourdieu, 1979:127 dalam Haryatmoko).

Dengan demikian dalam semua masyarakat, akan selalu ada yang menguasai dan dikuasai. Hubungan dominasi ini tergantung pada situasi, sumber daya (kapital) dan strategi pelaku. Pemetaan hubungan kekuasaan di dasarkan atas kepemilikan capitalkapital dan komposisi kapital tersebut. Kapital-kapital inilah yang memungkinkan untuk 
membentuk struktur lingkup sosial, dan diantara berbagai macam kapital yang ada kapital ekonomi dan kapital budaya merupakal hal yang akan menentukan dalam kriteria diferensiasi yang paling relevan bagi lingkup masyarakat yang sudah maju. Kiranya hal ini dapat menjadi refleksi kita dalam melihat realitas masyarakat ekonomi ASEAN dimana para pengambil kebijakan harus memastikan bahwa kerjasama internasional yang dilakukaan merupakan sebuah aktivitas pertukaran dalam perspektif pasar yang berarti tempat bertemunya penjual dan pembeli dengan tujuan yang saling menguntungkan. Bukan sebuah perdagangan yang bertujuan untuk saling menguasai dan berujung pada penjajahan.

\section{Kesimpulan}

Pada era konseptual seperti sekarang ini budaya dan seni manusia telah didukung oleh kemajuan teknologi informasi yang memberi dampak positif dan negatif. Jika dilihat dari perspektif positif teknologi dapat memudahkan proses pertukaran informasi, ide bahkan trade budaya yang terus mengalami perkembangan dan perubahan signifikan. Sementara dari perspektif negatifnya, kemajuan teknologi justru dapat memenjarakan kreatifitas manusia, karena terpedaya pada dunia maya yang jauh dari relitas kehidupan manusia. Sehingga kepekaan manusia sebagai mahluk sosial terkikis oleh teknologi.

Kedua perspektif inilah yang saat ini digunakan oleh masyarakat dalam melihat peristiwa seni. Sehingga tidak lagi cukup saat melihat seni hanya dalam tataran fungsional atau ekspesi saja. Keduanya menjadi teks yang terdapat dalam konteks budaya manusia, kemudaian akan memunculkan masalah-masalah yang lebih komplek bahkan multidisiplin. Hal inilah yang kemudian membutuhkan integrasi dan interkoneksi paradigma keilmuan dalam memahaminya.

Era konseptual adalah era yang secara ekonomi penting dan juga berharga secara personal. Tidak berhenti di situ nilai keindahan seni (estetika) juga dihadapkan oleh tuntutan nuansa fantastis namun juga menarik secara emosional. Fenomena inilah yang kemudian mempengaruhi produksi kebudayaan manusia saat ini. Dan bidang seni memiliki tempat yang strategis sebagai motor penggerak produksi kebudayaan tersebut. Maka titik temu sebagai jalan tengah antara keseimbangan dan harmoni adalah sebuah medium untuk melakukan eksplorasi seni.

Hubungan seni dan teknologi era global terdapat pada medium yang kemudian dikenal dengan istilah era new media art. Hal ini yang kemudian membawa perubahan refleksi estetika dalam budaya massa. Tujuanya adalah simulasi sempurna dalam mengomunikasikan ide dan gagasan keindahan untuk mewarnai kehidupan berbudaya. Namun dengan catatan kerjasama internasional yang dilakukaan merupakan sebuah aktivitas pertukaran dalam perspektif pasar yang berarti tempat bertemunya penjual dan pembeli dengan tujuan yang saling menguntungkan. Bukan sebuah perdagangan yang bertujuan untuk saling menguasai dan berujung pada penjajahan. Karena perlu kita perhatikan bersama adalah hubungan-hubungan kekuasaan dalam masyarakat yang merujuk pada logika posisi-posisi dan kepemilikan sumber daya (kapital). 


\section{Kepustakaan}

Aziz, Imam. 2001. Galaksi Simulacra. Yogyakarta: LkiS.

Bagus Lorens. 2005. Kamus Filsafat. Jakarta: PT. Gramedia Pustaka Utama cetakan ke empat, Chistiane Paul. 2015. Digital Art. New York: Thames \& Hudson.

Denys Lombard, Terj. Winarsih Partaningrat Arifin, Rahayu S. Hidyat, Nini Hidayati Yusuf.2008. Nusa Jawa: Silang Budaya, Jakarta: Gramedia Pustaka Utama.

Haryatmoko. 2010. "Teori Strukturasi Pierre Bourdieu dengan Orientasi Budaya". (Makalah) dipresentasikan di Pascasarjana Sosiologi Universitas Indonesia pada tanggal 26 Agustus 2010.

Koentjaraningrat. 1976. Pengantar Ilmu Antropologi Yogyakarta: Yayasan Obor

Krisna Murti. 2009. Essays on Video Art and New Media: Indonesia and Beyond, Yogyakarta: IVAA.

Kuntowijoyo. 1987. Budaya dan Masyarakat, Yogyakarta: Tiara Wacana. Matius Ali, 2009. Estetika. Tanggerang: Sanggar Luxor.

M. Agus Burhan. 2013. Seni Lukis Indonesia Masa Jepang Sampai Lekra, Surakarta:UNS Press.

M. Burhan Bungin. 2008. Sosiologi Komunikasi, Jakarta: Kencana Predana Media.

Misbach Yusa Biran. 2009. Sejarah Film 1900-1950: Bikin Film di Jawa. Depok: Komunitas Bambu.

Theodor W. Adorno. 2002. Translator's introduction by Robert Hullot-Kentor, Aesthetic Theory. London: Continum. 